\title{
РЕЗУЛЬТАТИ ОПЕРАТИВНОГО ЛІКУВАННЯ ХВОРИХ З ПРИВОДУ УСКЛАДНЕНОГО МICLЕВО-ПОШИРЕНОГО РАКУ ШЛУНКА
}

\section{В. О. Лазирський \\ Харківський національний медичний університет \\ RESULTS OF OPERATIVE TREATMENT IN PATIENTS, SUFFERING COMPLICATED LOCALLY-SPREAD GASTRIC CANCER}

\author{
V. O. Lazyrskyi
}

Kharkiv National Medical University

\begin{abstract}
Реферат
Проаналізовані результати оперативного лікування 418 хворих з приводу ускладненого місцево-поширеного раку шлунка (РШ). Перебіг основного захворювання ускладнений кровотечею - у $252(60,3 \%)$ пацієнтів, стенозом - у $89(21,3 \%)$, перфорацією - у 15 (3,5\%), їх поєднанням - у 62 (14,8\%). Радикальні операції виконані у 168 (40,2\%) хворих, паліативні та симптоматичні - у 250 $(59,8 \%)$. Після операції ускладнення виникли у 82 (19,6\%) хворих, післяопераційна летальність становила 7,2\% (померли 30 хворих).

Ключові слова: ускладнений місцево-поширений рак шлунка; хірургічне лікування.

Abstract

Results of operative treatment in 418 patients, suffering complicated locally-spread gastric cancer, were analyzed. The main disease course was complicated by hemorrhage in $252(60.3 \%)$ patients, by stenosis - in $89(21.3 \%)$, perforation - in $15(3.5 \%)$, their combination

- in $62(14.8 \%)$. Radical operations were performed in $168(40.2 \%)$ patients, while palliative and symptomatic - in 250 (59.8\%).

Postoperative complications have had occurred in 82 (19.6\%) patients, and lethality rate was $7.2 \%$ (30 patients died).

Keywords: complicated locally-spread gastric cancer; surgical treatment.
\end{abstract}

Незважаючи на тенденцію до зменшення захворюваності на РШ, проблема лікування його ускладнених форм є однією з найбільш актуальних [1 - 3]. До 60 - 80\% хворих госпіталізують 3 приводу занедбаних форм, тяжких ускладнень [2, 4]. Частота післяопераційних ускладнень становить від 16,3 до 48\%, летальність - від 8,3 до 37,2\% [2, 4 - 6].

Мета дослідження: покращення результатів лікування хворих 3 приводу ускладненого місцево-поширеного РШ.

\section{МАТЕРІАЛИ I МЕТОДИ ДОСЛІДЖЕННЯ}

Проаналізовані результати лікування 418 хворих 3 приводу місцево-поширеного РШ в клініці Інституту загальної та невідкладної хірургії імені В. Т. Зайцева НАМН України у 1996 - 2015 р. Вік хворих від 18 до 85 років, у середньому $(61,9$ $\pm 8,9)$ року. Чоловіків - $261(62,4 \%)$, жінок - 157 (37,6\%).

Хворі рандомізовані на дві групи: порівняння - 212 хворих (лікували у 2006 - 2010 р.), основну - 206 хворих (лікували у 2011 - 2015 р.). У гру- пі порівняння застосовували загальноприйняту хірургічну тактику, в основній групі - активно-індивідуалізовану двохетапну хірургічну тактику і розроблені комбіновані та реконструктивно-відновні оперативні втручання.

Ураження кардіальної частини шлунка відзначене у 41 (11,4\%) хворого, тіла шлунка - у 158 (41,1\%), вихідного відділу - у 112 (29,0\%), субтотальне - у 48 (11,2\% ), тотальне у 29 (7,3\%). Кровотеча виявлена у 252 (60,3\%) хворих, стеноз - у 89 (21,3\%), перфорація - у 15 (3,5\%), їх поєднання - у 62 (14,8\%). Крововтрата легкого ступеня (за класифікацією О. О. Шалімова, В. Ф. Саєнко, 1987) відзначена у 67 (16,0\%) хворих, середньої тяжкості - у 136 (32,5\%), тяжка - у 49 $(11,7 \%)$.

Низькодиференційована аденокарцинома діагностована у 156 (37,3\%) хворих, різного ступеня диференціювання - у 201 (48,1\%), перснеподібно-клітинний рак - у 61 (14,6\%). Розподіл хворих за стадією представлений у табл. 1.

Клінічні прояви пухлин шлунка у хворих представлені у табл. 2.

\section{РЕЗУЛЬТАТИ}

ТА ÏХ ОБГОВОРЕННЯ

У клініці протягом багатьох років надають кваліфіковану допомогу хворим з приводу злоякісних новоутворень шлунка з гострими життезагрожуючими ускладненнями, зокрема, кровотечею, стенозом, перфорацією. Прийнята двохетапна тактика лікування хворих на основі широкого використання мініінвазивних втручань.

Кровотеча ускладнює перебіг РШ у 2,7 - 41\% спостережень, посідає 2 - 3-тє місце серед інших ускладнень $[2-4,7]$. Для оцінки стану гемостазу використовували класифікацію активності кровотечі J. А. Н. Forrest в модифікації В. І. Нікішаєва (1997) [7] Метод ендоскопічного гемостазу передбачав первинну оцінку джерела кровотечі, ендоскопічне кліпування судин, що кровоточать, коагуляцію і кріовплив, зрошення пухлини, що кровоточить, розчином гемостатиків. Досягнення тимчасового ендоскопічного гемостазу у 49 (11,7\%) хворих за наявності кровотечі, що тривала, дозволило провести інтенсивну передопераційну підготов- 
ку і виконати відстрочене оперативне втручання у строки $2-6$ діб після госпіталізації.

На першому етапі рентгеноендоваскулярний гемостаз застосований у $31(7,4 \%)$ хворого, з них у $13(3,1 \%)$ - це стало самостійним методом лікування (у 9 - рецидиву кровотечі не було). Метод особливо цінний для досягнення гемостазу у пацієнтів старечого віку з вираженими супутніми захворюваннями за високого ступеня операційного ризику виконання відкритого оперативного втручання.

Застосування на першому етапі мініінвазивних методів гемостазу дозволило зменшити частоту виконання невідкладних операцій: в групі порівняння - у 46 (11,0\%), в основній групі - у 13 (3,1\%). У відстроченому порядку операції виконані у 80 (19,1\%) хворих, з них у 59 (14,1\%) основної групи.

У клініці прийнята тактика, спрямована, насамперед, на досягнення надійного гемостазу. При можливості виконання радикального оперативного втручання застосовуємо одноетапні операції, за високого операційного ризику - двохетапну тактику (I етап - паліативна резекція шлунка з пухлиною; II етап - радикальна ререзекція шлунка - гастректомія з адекватною лімфодисекцією і резекцією уражених суміжних органів). Особливістю паліативної резекції є те, що при виключенні повторних втручань перевагу віддаємо методикам в модифікації Більрот - II, при планованому повторному втручанні - методикам за Більрот I. Як паліативні операції, що забезпечують припинення кровотечі, за наявності пухлин шлунка, що неможливо видалити, застосовували гастротомію 3 прошиванням судин, що кровоточать, тампонаду кратера пухлинної виразки пасмом великого сальника на живильній судинній ніжці за Опелем-Полікарповим; а також розроблений в клініці метод тампонади виразок пухлини передньою стінкою шлунка.

На висоті кровотечі оперовані 40 (9,5\%) хворих, з них 8 (1,9\%) - основної групи. Радикальні операції виконані у 5 (12,5\%) 3 них, у 4 - комбінована резекція шлунка. Післяопераційні ускладнення виникли у 15 (37,5\%), померли 5 (12,5\%)

Таблиця 1. Розподіл хворих на РШ за стадією (за класифікацією TNM)

\begin{tabular}{|ccccc|}
\hline \multirow{2}{*}{ Показник } & \multicolumn{4}{c|}{ Кількість спостережень в групах } \\
\cline { 2 - 5 } & \multicolumn{3}{c|}{ основній } & \multicolumn{2}{c|}{ порівняння } \\
\cline { 2 - 5 } & абс. & $\%$ & абс. & $\%$ \\
\hline T4 & 206 & 49,3 & 212 & 50,7 \\
\hline N0 & 15 & 3,5 & 29 & 6,9 \\
\hline N1 & 112 & 26,8 & 122 & 29,2 \\
\hline N2 & 64 & 15,3 & 48 & 11,5 \\
\hline N3 & 15 & 3,5 & 13 & 3,1 \\
\hline M- & 206 & 49,3 & 212 & 50,7 \\
\hline P3 & - & - & 12 & 2,8 \\
\hline P4 & 206 & 49,3 & 200 & 47,8 \\
\hline
\end{tabular}

\begin{tabular}{|lcccc|}
\hline Tаблиця 2. & Розподіл хворих на РШ за клінічними проявами \\
\hline \multirow{2}{*}{ Симптом } & \multicolumn{4}{c|}{ Кількість спостережень в групах } \\
\cline { 2 - 6 } & \multicolumn{3}{c|}{ основній } & \multicolumn{3}{c|}{ порівняння } \\
\cline { 2 - 6 } & абс. & $\%$ & абс. & $\%$ \\
\hline Кровотеча & 123 & 29,4 & 129 & 30,8 \\
\hline Стеноз & 42 & 10,0 & 47 & 11,2 \\
\hline Перфорація & 9 & 2,1 & 6 & 1,4 \\
\hline Поєднання ускладнень & 32 & 7,6 & 30 & 7,2 \\
\hline Разом ... & 206 & 49,3 & 212 & 50,7 \\
\hline
\end{tabular}

хворих. Паліативна резекція шлунка виконана у 47 (11,2\%) хворих при кровотечі з пухлини.

Під час резекції шлунка віддаємо перевагу формуванню езофагоєюноанастомозу в нашій модифікації і модифікації Ру (при реконструктивних операціях). 31989 р. в клініці, поряд з стандартними, застосовуємо власну методику накладання езофагоєюноанастомозу, що передбачає фіксацію привідної петлі позаду стравоходу в задньому середостінні; накладення провізорних стравохідно-діафрагмальних швів на передню стінку стравоходу; формування антирефлюксного анастомозу шляхом інвагінації його у відвідну петлю тонкої кишки. Простота запропонованої методики, зменшення тривалості втручання до мінімуму дозволили застосовувати іiі під час виконання гастректомії на висоті кровотечі 3 хорошими результатами (пат. України 11127 від 06.05.99).

Виникнення кровотечі 3 арозованих судин суміжних органів вважали додатковим показанням до застосування комбінованих операцій. При раку кардіальної частини шлунка можливе застосування його проксимальної резекції або гастректомії. Ми поділяємо думку інших авторів [2], що на висоті кровотечі виконання гастректоміі, в порівнянні
3 проксимальною резекцією шлунка, більш виправдане, технічно простіше, надійніше і більш радикальне, супроводжується меншою частотою післяопераційних ускладнень і меншою летальністю. При раку тіла і дистальних відділів шлунка, що кровоточить,показане виконання гастректомії та субтотальної дистальної резекції шлунка з лімфодисекцією. Разом з тим, за тяжкого стану пацієнта, поширеного пухлинного процесу доцільне застосування паліативної резекції, включаючи атипову. На відновному етапі перевагу віддаємо модифікаціям резекції за Більрот-II.

Особливою категорією є хворі 3 пухлинами кукси шлунка, що кровоточать. Радикалізм щодо пухлини і гемостазу досягається шляхом екстирпації кукси шлунка 3 лімфодисекцією. Комбінована екстирпація кукси шлунка виконана у 15 хворих (9 - основної групи, 6 - групи порівняння), у 10 - 3 резекцією товстої кишки, доповненою у 2 хворих спленектомією, у 5 - з резекцією підшлункової залози і спленектомією. Помер один хворий внаслідок легенево-серцевої недостатності. При кровотечі $з$ нерезектабельних пухлин кукси шлунка єдино можливими є ендоскопічні та рентгеноендоваскулярні гемостатичні методи- 
ки, застосовані у 4 хворих. У 2 хворих виник рецидив кровотечі з летальним наслідком.

Перфоративний РШ. Перфорацію РШ виявляють у $2,1-11,5 \%$ спостережень, причому, таке ускладнення нерідко є першим проявом захворювання [2, 5]. До операції неможливо встановити поширення ракової пухлини, стадію захворювання, ураження лімфатичних вузлів, проростання суміжних органів.

Перфорація РШ відзначена у 19 (4,5\%) хворих. При перфорації пухлин шлунка загальноприйнятою операцією $є$ первинна резекція шлунка. Протипоказаннями до неї є тяжкий загальний стан пацієнта, літній і старечий вік, перитоніт, високе розташування пухлини, проростання сусідніх органів. За таких ситуацій застосовуємо двохетапну тактику. Першим етапом зашивали перфоративний отвір (перевагу віддавали методиці Опеля-Полікарпова 3 тампонадою перфоративного отвору великим сальником на ніжці); другим етапом виконували відстрочену резекцію шлунка. Двохетапні втручання виконані у 9 хворих з приводу перфорації пухлини шлунка. У 4 3 них під час виконання відстроченої операції вдалося здійснити радикальну комбіновану гастректомію, у 5 - паліативну резекцію шлунка. У 2 хворих після зашивання перфоративного отвору виникла профузна кровотеча, в 1 - неспроможність швів з летальним наслідком. У решти 10 хворих виконана первинна резекція шлунка (у 4 - паліативна). Померли 2 хворих внаслідок перитоніту.

Стеноз шлунка за його пухлинного ураження виявляють у 7,5 - 25,4\% хворих $[1,2,5]$. Через виражене зневоднення, білковий дефіцит, анемію, порушення згортання крові, хворим потрібне проведення передопераційної підготовки, спрямованої на корекцію показників гомеостазу. Поряд з інфузійною терапією, активно використовуємо трансдуоденальне введення поживних речовин і рідини через ендоскопічно введений для годування зонд або ендоскопічно встановлений стент. Під час оперативного втручання стент видаля- ли разом з пухлиною. Наявність цього ускладнення при виконанні радикальної операції суттєво не впливає на обсяг втручання за умови компенсації основних життевих функцій.

3 симптоматичних оперативних втручань перевагу віддаємо обхідній гастроентеростомії (накладання попередуободового ізоперистальтичного гастроентероанастомозу на довгій петлі з браунівським співустям за Вельфлером). За короткої брижі тонкої кишки формували задній позадуободовий анастомоз за Гакером; за короткої брижі тонкої кишки і ураження задньої стінки шлунка - передній позадуободовий гастроентероанастомоз за Більрот; при ураженні передньої стінки шлунка і брижі ободової кишки метастазами - задній попередуободовий анастомоз за Монастирським. В окремих ситуаціях при занедбаній стадії захворювання для забезпечення харчування хворого формували єюно- або гастростому. При стенозуючому раку кардії може бути застосована проксимальна резекція шлунка або гастректомія, залежно від морфологічних характеристик пухлини. При нерезектабельних пухлинах кардії застосовували реканалізацію пухлини, формували гастростому або еюностому за Майдлем. Операцією вибору з приводу стенозуючих пухлин тіла шлунка є гастректомія, рідше - субтотальна дистальна резекція шлунка, ще рідше - різні види атипової резекції шлунка. Слід підкреслити доцільність виконання резекційних втручань навіть як паліативного заходу, оскільки за такої локалізації стенозуючої пухлини шлунка формування гастростоми або обхідного анастомозу неможливе. Сдино можливим методом забезпечення харчування хворого є єюностомія за Майдлем, якість життя після якої незадовільна.

3 приводу стенозуючих пухлин пілороантрального відділу шлунка операцією вибору є субтотальна дистальна резекція шлунка. 3 огляду на злоякісний характер процесу стенозування, віддаємо перевагу формуванню гастроентероанастомозу на короткій петлі за ГофмейстеромФінстерером.
Стеноз шлунка відзначений у 89 хворих ізольовано, разом - у 104 (24,8\%) спостереженнях. За рентгенологічною класифікацією Лінденбратена, стеноз у стадії компенсації виявлений у 42 (10\%) хворих, субкомпенсації - у 46 (11\%), декомпенсації - у 16 (3,8\%). Радикальні операції виконані у 26 (6,2\%) хворих цієї групи, паліативна гастректомія - у 7 (1,7\%), резекція шлунка - у 18 (4,3\%). У 53 (12,6\%) хворих виконані симптоматичні операції: обхідний гастроентероанастомоз накладений у 42 (10\%) хворих, в 11 - сформовано єюно- або гастростому.

У 168 (40,2\%) хворих виконано комбіновану резекцію шлунка 3 лімфодисекцією в обсязі D2 (з них у 106 - основної групи). Комбінована гастректомія з резекцією поперечної ободової кишки та іï брижі виконана у 36 (8,6\%) хворих, резекцією печінки - у 35 (8,3\%), підшлункової залози в поєднанні з спленектомією і без такої - у 32 (7,6\%), спленектомією - у 14 (3,3\%); у 51 (12,2\%) хворого виконано мультивісцеральну резекцію. При резекції шлунка в поєднанні з резекцією поперечної ободової кишки здійснювали гастропластику з використанням ілеоцекального сегмента кишечнику (у 18 хворих).

Паліативні і симптоматичні операції виконані у 250 (59,8\%) хворих. Післяопераційні ускладнення виникли у 82 (19,6\%) хворих, післяопераційна летальність становила 7,2\% (померли 30 хворих).

\section{ВИСНОВКИ}

1. У хворих за ускладненого місцево-поширеного РШ доцільним є застосування двохетапної хірургічної тактики з широким використанням мініінвазивних оперативних втручань.

2. Впровадження запропонованої хірургічної тактики і нових оперативних втручань сприяло збільшенню частоти виконання радикальних операцій: у 62 (14,8\%) хворих в групі порівняння, у 106 (25,3\%) - в основній групі; зменшенню післяопераційної летальності з 8,0 до 6,3\%. 


\section{ЛITEPATУPA/REFERENCES}

1. Bondar VG. Kombinirovannoe vmeshatelstvo po povodu mestnorasprostranennogo raka distalnogo otdela zheludka. Klinichna khirurgiia. 2004;(1):24-6. [In Russian].

2. Geshelin SA. Neotlozhnaya onkokhirurgiya. Kiev: Zdorov'ya; 1988. 200 s. [In Russian].

3. Polikarpov SA, Lisitskij AN, Irov NN, i dr. Radikalnoe khirurgicheskoe lechenie raka zheludka, oslozhnennogo profuznym krovotecheniem. Khirurgiya. 2008;(7):24-6. [In Russian].

4. Mikhaylov AP, Danilov AM, Napalkov AN, i dr. Ostrye zheludochnokishechnye krovotecheniya opukholevoj etiologii. Vestnik khirurgii im. I. I. Grekova. 2006;(4):79-81. [In Russian].
5. Gromov MS, Aleksandrov DA, Kulakov AA, i dr. Diagnostika i lechenie rasprostranennogo raka zheludka. Khirurgiya. 2003;(4):20-3. [In Russian].

6. Davydov MI, Ter-Ovanesov MD, Abdikhakimov AN, Marchuk AN Rak zheludka: chto opredelyaet standarty khirurgicheskogo lecheniya. Prakticheskaya onkologiya. 2001;(7):18-24. [In Russian].

7. Fomin PD, Ivanchov PV, Zaplavskyi OV. Khirurhichni aspekty kardioezofahealnoho raku, shcho hostro krovotochyt. Kharkivska khirurhichna shkola. 2009;4.1.(36):303-5. [In Ukrainian]. 